\title{
PEMBIASAAN KARAKTER ISLAM DALAM PENGEMBANGAN BUKU AJAR \\ BAHASA JAWA PIWULANG 5 PENGALAMANKU KELAS I MI NURUR ROHMAH JASEM SIDOARJO
}

\author{
${ }^{1}$ Nurdyansyah, ${ }^{2}$ Renti Pujiana Lestari \\ ${ }^{1,2}$ Fakultas Agama Islam Universitas Muhammadiyah Sidoarjo \\ Jl. Majapahit, 666 B Sidoarjo Telp.031-8945444; Fax. 031-8949333 \\ Email: ${ }^{1}$ nurdyansyah@umsida.ac.id/ ${ }^{2}$ renti.pujiana8@gmail.com
}

\begin{abstract}
The purpose of this research are: 1) designing and explaining the feasibility of Basa Jawi skilled textbooks in 5 experiences based on the character of Islam in class I MI Nurur Rohmah Jasem Sidoarjo. 2) explain how much improvement in learning outcomes in the development and implementation of Basa Jawi skilled textbooks 5 my experiences based on the character of Islam in class I MI Nurur Rohmah Jasem Sidoarjo.

The type of research used is research and development or Research and Development. The resulting development product is Basa Jawi's skilled textbooks, my 5 experiences based on Islamic character for first grade students MI Nurur Rohmah Jasem Sidoarjo. The development model used by the researcher is Walter Dick and Lou Carey with 9 stages of learning design, including: identification of learning objectives, learning analysis, identification of initial behaviors, determining specific learning objectives to develop benchmark reference assessments, developing learning strategies, selecting and developing learning materials, designing and carry out formative evaluations, and revisions.

The results of the development of textbooks meet valid criteria with design expert validation results reaching $30 \%$, content expert validation results reaching $60 \%$, language expert validation results reaching $40 \%$, individual trial results reaching $100 \%$, small group trials reaching $94 \%$, and the results of large group trials reached $72 \%$. The results of the test analysis using SPSS 15 which shows the p-value value of the test statistic is 0.00 which means $(<0.05)$, it can be concluded that Ho is rejected by Ha accepted. This means that there is a significant influence on the average scores pretest and posttest. And the results of the evaluation of religious character and responsibility have changed greatly after using Basa Jawi skilled textbooks in my 5 experiences based on Islamic character in class I in MI Nurur Rohmah Jasem Sidoarjo.
\end{abstract}

Keywords: Basa Jawi's Textbook, Piwulang 5 My Experience, Islamic Character 


\begin{abstract}
Abstrak
Tujuan penelitian dan pengembangan ini meliputi: 1) mendesain dan menjelaskan kelayakan buku ajar trampil Basa Jawi piwulang 5 pengalamanku berbasis karakter islam di kelas I MI Nurur Rohmah Jasem Sidoarjo. 2) menjelaskan seberapa besar peningkatan hasil belajar dalam dikembangkan dan diterapkannya buku ajar trampil Basa Jawi piwulang 5 pengalamanku berbasis karakter islam di kelas I MI Nurur Rohmah Jasem Sidoarjo.

Jenis penelitian yang digunakan yaitu penelitian dan pengembangan atau Research and Development. Produk pengembangan yang dihasilkan adalah buku ajar trampil Basa Jawi piwulang 5 pengalamanku berbasis karakter islam untuk siswa kelas I MI Nurur Rohmah Jasem Sidoarjo. Model pengembangan yang digunakan peneliti adalah Walter Dick anf Lou Carey dengan 9 tahapan desain pembelajaran, diantaranya: identifikasi tujuan pembelajaran, analisis pembelajaran, identifikasi perilaku awal, menentukan tujuan pembelajaran khusus mengembangkan penilaian acuan patokan, mengembangkan strategi pembelajaran, memilih dan mengembangkan materi pembelajaran, merancang dan melaksanakan evaluasi formatif, dan revisi.

Hasil dari pengembangan buku ajar memenuhi kriteria valid dengan hasil validasi ahli desain mencapai $30 \%$, hasil validasi ahli konten mencapai $60 \%$, hasil validasi ahli bahasa mencapai $40 \%$, hasil uji coba perseorangan mencapai $100 \%$, uji coba kelompok kecil mencapai 94\%, dan hasil uji coba kelompok besar mencapai 72\%. Hasil analisis uji $t$ menggunakan SPSS 15 yang menunjukkan nilai $\mathrm{p}$-value statistik uji $\mathrm{t}$ adalah sebesar 0.00 yang berarti $(<0.05)$, maka dapat disimpulkan bahwa Ho ditolak Ha diterima. Hal tersebut berarti terdapat pengaruh yang signifikan pada rata-rata nilai pretest dan postest. Dan hasil penilaian karakter religius dan tanggungjawab mengalami perubahan yang sangat meningkat setelah menggunakan buku ajar trampil Basa Jawi piwulang 5 pengalamanku berbasis karakter islam kelas I di MI Nurur Rohmah Jasem Sidoarjo.
\end{abstract}

Kata kunci: Buku Ajar Bahasa Jawa, Piwulang 5 Pengalamanku, Karakter Islam

\title{
A. PENDAhuluan
}

Pendekatan pembelajaran sangat penting dan berpengaruh besar dalam perkembangan dunia pendidikan. ${ }^{1}$ Sebagaimana penjelasan dalam UU pasal 1 ayat 2 Nomor 20 Tahun 2003 mendeskripsikan: "Pendidikan nasional adalah pendidikan yang berdasarkan Pancasila dan UUD yang berakar pada nilai-nilai agama, kebudayaan nasional Indonesia dan tanggap terhadap tuntutan zaman. Oleh karena itu, perancangan dan perkembangan pembelajaran harus sesuai dengan perkembangan IPTEK. ${ }^{2}$

\footnotetext{
${ }^{1}$ M. Musfiqon dan Nurdyansyah. N. (2015). Pendekatan Pembelajaran Saintifik. Sidoarjo: Nizamia learning center., 41

${ }^{2}$ Nurdyansyah \& Luly Riananda. (2016). Developing ICT-Based Learning Model to Improve Learning Outcomes IPA of SD Fish Market in Sidoarjo, Proceedings of International Research Clinic \& Scientific Publications of Educational Technology. Jurnal TEKPEN, Jilid 1, Terbitan 2, 929-930.
} 
Nurdyansyah memperjelas "The education world must innovate in a whole. It means that all the devices in education system have its role and be the factors which take the important effect in successful of education system". ${ }^{3}$

Dunia pendidikan tidak boleh hanya melibatkan siswa atau guru saja dalam proses pembelajaran melainkan harus melibatkan banyak pihak. ${ }^{4}$ Karena hakikat belajar adalah suatau proses pengarahan dalam rangka mencapai tujuan tertentu dalam pembelajaran melalui pengalaman yang diciptakan dan terukur. ${ }^{5}$

Dalam rangka pencaian tujuan tersebut perlu ada bahan ajar dalam pembelajaran yang dapat membantu mencapai tujuan tersebut. Bahan ajar merupakan suatu alat atau seperangkat materi untuk membantu mencapai kompetensi yang telah ditentukan. ${ }^{6}$ Untuk mencapai kompetensi tersebut juga dibutuhkan adanya pengukuran / penilaian. Adapun kreteria dalam penilaian hasil belajar memerlukan sebuah pengolahan dan analisis yang akurat. ${ }^{7}$

Namun dunia pendidikan kita saat ini menghadapi berbagai masalah yang amat kompleks dan perlu mendapatkan perhatian khusus bagi kita semua.Karena kondisi masyarakat Indonesia saat ini sudah sangat memprihatinkan. Keprihatinan yang sangat mendalam adalah karena telah begitu meluasnya krisis moral yang melahirkan berbagai perbuatan buruk yang dilakukan oleh hampir setiap orang. Salah satu masalah tersebut adalah menurunnya norma suatu kehidupan, baik itu sosial ataupun etika moral dalam praktik kehidupan sekolah yang dapat mengakibatkan terjadinya sejumlah perilaku negatif yang sangat merisaukan masyarakat. Hal tersebut antara lain makin banyaknya penyimpangan berbagai norma kehidupan agama dan sosial kemasyarakatan. ${ }^{8}$

Pada era globalisasi ini, kemajuan IPTEK (Ilmu Pengetahuan dan Teknologi) disamping dapat membawa dampak yang positif bagi kemajuan bangsa, juga menimbulkan dampak negatif yang cukup meresahkan masyarakat, khususnya mengenal degradasi moral remaja, karena pemuda adalah harapan bagi kehidupan dimasa depan dan penerus cita-cita

3 Nurdyansyah, Pandi Rais, Qorirotul Aini. (2017). The Role of Education Technology in Mathematic of Third Grade Students in MI Ma'arif Pademonegoro Sukodono. Madrosatuna: Journal of Islamic Elementary School Vol. 1 (1), November 2017, 37-46 ISSN 2579. 38.

4 Nurdyansyah. N., Andiek Widodo, Inovasi Teknologi Pembelajaran. (Sidoarjo:Nizamia Learning Center,2015), 2.

${ }^{5}$ Nurdyansyah. N., Eni fariyarul Fahyuni, Inovasi Model Pembelajaran Sesuai Kurikulum 2013 (Sidoarjo:Nizamia Learning Center,2016), 1.

${ }^{6}$ Ika Lestari. (2013). Pengembangan BahanAjar Berbasis Kompetensi (Sesuaidengan Kurikulum TingkatSatuan Pendidikan). Padang:Akademia Permata.134

${ }^{7}$ Nurdyansyah. N., Andiek Widodo, Manajemen Sekolah Berbasis ICT. (Sidoarjo:Nizamia Learning Center,2015), 103.

${ }^{8}$ Baharuddin, Pendidikan dan Psikologi Perkembangan, (Yogyakarta: Ar-Ruzz Media, 2009), 229. 
orang tua, bangsa dan agama. Disamping itu, pemuda adalah pemegang tingkat estafet kepemimpinan umat dimasa depan. ${ }^{9}$

Dengan melihat problem pendidikan yang memprihatinkan dan kemajuan IPTEK yang berdampak positif dan negatif. Buku ajar di sekolah atau lembaga formal mempunyai posisi yang strategis dalam peranan karakter, dimaksudkan untuk mengarahkan perubahan dalam diri siswa secara terencana, baik perubahan dalam pengetahuan, pemahaman, karakter dan keterampilan.Tidak hanya pembelajaran yang diadakan disekolah saja tetapi juga dipengaruhi oleh lingkungan belajar atau non formal untuk membina mereka supaya berakhlakul karimah.

Oleh karena itu pengembangan karakter Islam sangat diperlukan untuk menciptakan generasi yang santun dalam bertutur kata dan berakhlakul karimah. Sebagaimana sabda Rasulullah $\mathrm{SAW}^{10}$ :

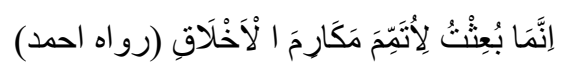

Artinya : "Sesungguhnya aku diutus hanyalah untuk menyempurnakan akhlak yang mulia."

Firman Allah SWT :

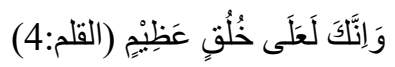

Artinya : "Dan sesungguhnya kau (Muhammad) benar-benar berbudi pekerti yang agung."

Adanya pembelajaran bahasa diharapkan peserta didik dapat mengenal dirinya, budayanya, dan budaya orang lain, mengemukakansuatu gagasan dan perasaan, ikut berpartisipasi dalam masyarakat yang menggunakan bahasa tersebut, dan menemukan serta menggunakan kemampuan analitis dan imaginatif yang ada dalam dirinya. ${ }^{11}$

Selain bahasa yang di gunakan yang menjadi faktor penting adalah karakter yang dapat terbentuk melalui bahasa yang kita gunakan.Bahasa jawa memiliki karakteristik bahasa yang berupa bahasa ngoko dan krama. Dalam realita di lapangan, pendidik masih menggunakan buku ajar bahasa jawa yang kurang inovatif (gambar, warna, dll), buku teks yang digunakan saat ini hanya menekankan pada kemampuan akademik yang tidak disertai hal-hal yang dapat meningkatkan kecerdasan intelektual dan sosial, dan pendidik berpacu pada penggunaan LKS

\footnotetext{
${ }^{9}$ Abuddin Nata, Manajemen Pendidikan: Mengatasi Kelemahan Pendidikan Islam Di Indonesia, (Jakarta : Kencana 2008), 198

${ }^{10}$ Ridwan Abdullah Sani dan Muhammad Kadri, Pendidikan Karakter: Mengembangkan karakter anak yang islami, (Jakarta: Bumi Aksara, 2016), 19

${ }_{11}$ Departemen Agama, Kantor Wilayah Provinsi Jawa Timur, Standar Nasional Pendidikan UU PERMEN NO 22 TAHUN 2006 TENTANG Standar Isi (Surabaya, 2006), 317
} 
(Lembar Kerja Siswa) di karenakan buku ajar yang dirasa menggunakan bahasa yang kurang di pahami siswa.

Dengan demikian, hasil yang didapat adalah buku ajar yang mereka pakai kurang menarik.Seorang pendidik dituntut kreativitasnya untuk mampu menyusun buku ajar yang inovatif, variatif, menarik, kontekstual, dan sesuai dengan tingkat kebutuhan peserta didik.

Melihat begitu banyaknya permasalahan yang didapatkan di lapangan, yaitu kemrosotan akhlak peserta didik dalam berbicara (bahasa ngoko kasar) sehingga keluar dari karakter Islam, sopan santun terhadap Orang Tua maupun Guru, dan di Era global yang seperti ini kebanyakan anak-anak sulit memahami kosakata dalam bahasa jawa dan menulis bahasa jawa dengan benar, dengan pembelajaran bahasa jawa berbasis karakter islam diharapkan dapat memberikan hasil yang maksimal.

Oleh karena itu guru dituntut untuk melaksanakan pembelajaran aktif dengan mengeksplorasi dan mengelaborasi semua kemampuan peserta didik dengan mengintegrasikan nilai-nilai karakter dan menggunakan media yang menyenangkan. Sehingga guru di tuntut untuk memilih dan menggunakan bahan pembelajaran.

Dengan demikian, pengembangan buku ajar di sekolah harus memperhatikan karakteristik siswa dan kebutuhan siswa sesuai kurikulum, yaitu menuntut adanya partisipasi dan aktivasi siswa lebih banyak dalam pembelajaran. Pengembangan buku ajar menjadi alternatif yang akan bermanfaat dan mempermudah bagi siswa dalam proses pembelajaran berlangsung. Sehingga buku ajar ini menambah informasi tentang materi yang dipelajari melalui kegiatan belajar secara sistematis. ${ }^{12}$ Melihat fenomena yang terjadi di Era Globalisasi ini, peneliti tergugah untuk mengembangkan Buku Ajar Bahasa Jawa piwulang 5 Pengalamanku Berbasis Karakter Islam Kelas 1 MI Nurur Rohmah Jasem Sidoarjo

\section{B. METODE PENELITIAN}

Pengembangan buku ajar ini menggunakan jenis penelitian pengembangan research and Development.Metode penelitian dan pengembangan (Research and Development) adalah metode penelitian yang digunakan untuk menghasilkan produk tertentu, dan menguji keefektifan produk tersebut. ${ }^{13}$ Penelitian yang peneliti kembangkan menggunakan model penelitian R\&D karena berusaha mengembangkan suatu produk berupa buku ajar pada aspek

\footnotetext{
${ }^{12}$ Hetty Rusyanti, pengertian bahan ajar menurut para ahli, 2016).

(http://www.kajianteori.com/2014/02/pengertian bahan ajar menurut ahli.html, diakses tanggal 10 oktober

${ }^{13}$ Sugiyono, Metode Penelitian Kuantitatif, Kualitatif, dan R\&D, (Bandung: Alfabeta, 2014), 297
} 
berkarakter islam. Penelitian ini difokuskan pada materi Bahasa Jawa piwulang 5 Pengalamanku. Penelitian ini menggunakan model pengembangan pembelajaran Walter dick and louy Carey, ${ }^{14}$

\section{Gambar Rancangan Pembelajaran Model Dick \& Carey}

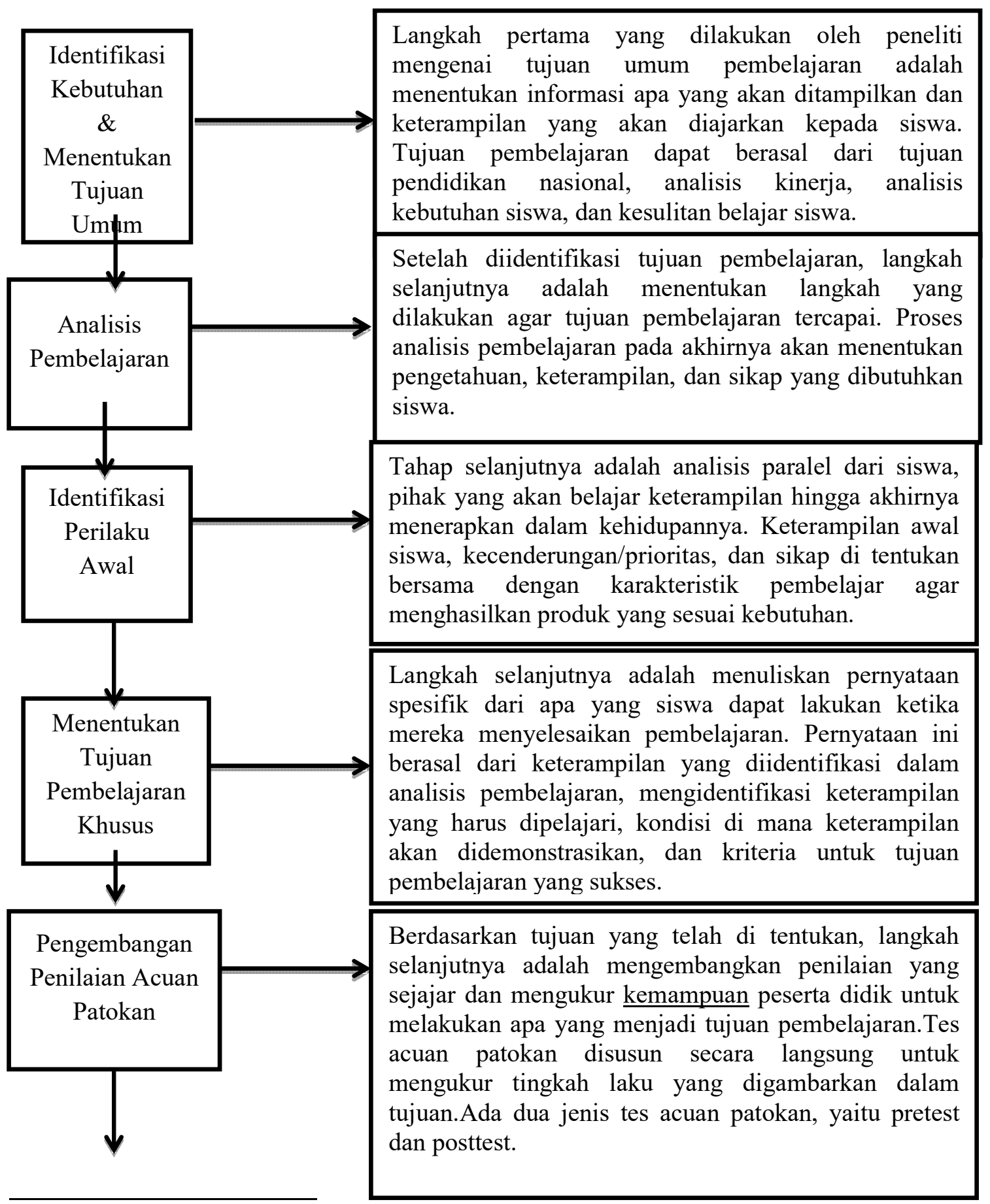

14 Walter Dick and Lou Carey, The Systematic Design of Instruction, (New York: Harper CollinsPublishers, 2001), 8-11 dapat dilihat di http://elinady.blogspot.co.id/2014/03/pembelajaran-dick-andcarey.html diakses pada tanggal 12 November 2016 pukul 10.15 wib 


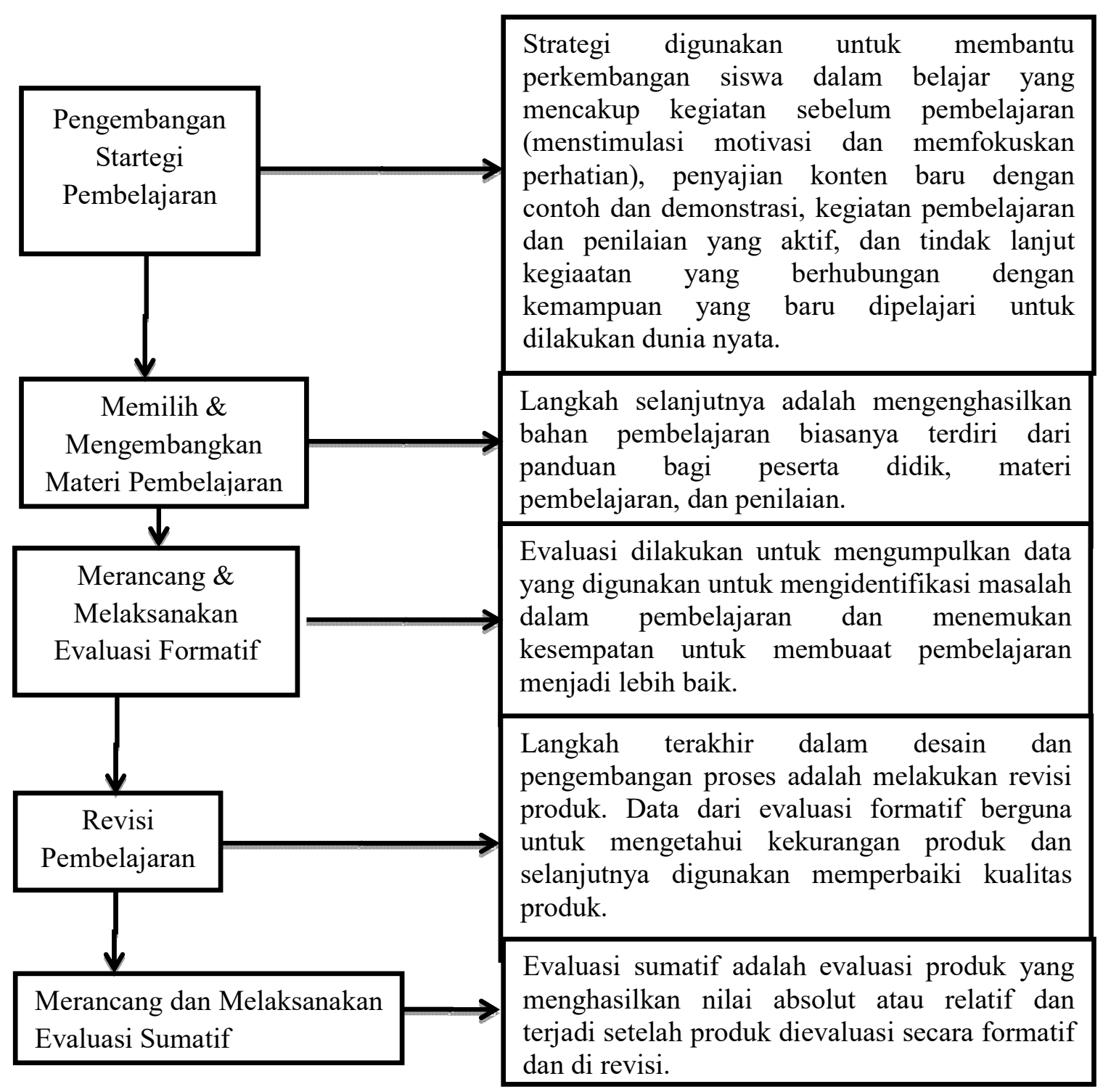

Pada model pengembangan Dick and carey terdapat 10 tahapan yang merupakan sebuah prosedur yang menggunakan pendekatan sistem dalam mendesain sebuah program pembelajaran, tetapi pada penelitian pengembangan ini peneliti hanya menggunakan 9 tahapan. Hal ini di lakukan melalui pertimbangan bahwa pengembangan buku ajar yang dilakukan hanya sebatas pada uji coba prototipe produk.

\section{HASIL PENELITIAN}

Berikut ini merupakan hasil uji beda (Uji T) siswa, baik pretest maupun posttest.

a. Uji Beda (Uji T) Hasil Pretest dan Posttest 
Paired Samples Statistics

\begin{tabular}{|ll|l|r|r|c|}
\hline & & & & Std. Error \\
& & Mean & $\mathrm{N}$ & Std. Deviation & Mean \\
\hline Pair & Pretest & 60,4000 & 25 & 16,45195 & 3,29039 \\
1 & Posttest & 86,8000 & 25 & 11,07550 & 2,21510 \\
\hline
\end{tabular}

Paired Samples Correlations

\begin{tabular}{|ll|r|r|c|}
\hline & \multicolumn{1}{|c|}{$\mathrm{N}$} & Correlation & Sig. \\
\hline Pair 1 & Pretest \& Posttest & 25 &, 693 &, 000 \\
\hline
\end{tabular}

Paired Samples Test

\begin{tabular}{|c|c|c|c|c|c|c|c|c|}
\hline & \multicolumn{5}{|c|}{ Paired Differences } & \multirow[b]{3}{*}{$\mathrm{t}$} & \multirow[b]{3}{*}{ df } & \multirow[b]{3}{*}{ Sig. (2-tailed) } \\
\hline & \multirow[b]{2}{*}{ Mean } & \multirow[b]{2}{*}{ Std. Deviation } & \multirow{2}{*}{$\begin{array}{c}\text { Std. Error } \\
\text { Mean }\end{array}$} & \multicolumn{2}{|c|}{$\begin{array}{c}95 \% \text { Confidence } \\
\text { Interval of the } \\
\text { Difference }\end{array}$} & & & \\
\hline & & & & Lower & Upper & & & \\
\hline Pair 1 Pretest - Posttes & 26,40000 & 11,86030 & 2,37206 & $-31,29569$ & $-21,50431$ & $-11,130$ & 24 &, 000 \\
\hline
\end{tabular}

Berdasarkan nilai mean atau nilai rata-rata pada tabel di atas dapat diketahui perbedaan antara hasil belajar pretest dan posttest, yaitu hasil pretest menunjukkan nilai rata-rata 60,40 dan hasil posttest menunjukkan nilai rata-rata 86,80. Oleh karena itu nilai p-value statistik uji $\mathrm{t}$ adalah sebesar 0.00 yang berarti $(<0.05)$, maka dapat disimpulkan bahwa Ho ditolak Ha diterima. Hal tersebut berarti terdapat pengaruh yang signifikan pada rata-rata nilai pretest dan postest.

b. Uji Nilai hubungan buku ajar bahasa jawa piwulang 5 pengalamanku dengan hasil belajar posttest

Descriptive Statistics

\begin{tabular}{|l|r|r|r|}
\hline & \multicolumn{1}{|c|}{ Mean } & Std. Deviation & \multicolumn{1}{|c|}{$\mathrm{N}$} \\
\hline Posttest & 86,8000 & 11,07550 & 25 \\
Buku Ajar Bahasa Jawa & 9,7200 &, 67823 & 25 \\
\hline
\end{tabular}

Tabel di atas menggambarkan nilai rata-rata dan standar deviasi dari nilai hasil belajar posttest dan buku ajar bahasa jawa piwulang 5 pengalamanku. Rata-rata nilai hasil belajar posttest adalah 86,80 dengan standar deviasi 11,07. Rata-rata nilai buku ajar bahasa jawa piwulang 5 pengalamanku yang diterapkan peneliti adalah 9,72 dengan standar deviasi 0,67.

Correlations

\begin{tabular}{|ll|r|r|}
\hline & & \multicolumn{1}{|c|}{$\begin{array}{c}\text { Buku Ajar } \\
\text { Bahasa Jawa }\end{array}$} \\
\hline Pearson Correlation & Posttest & 1,000 &, 153 \\
& Buku Ajar Bahasa Jawa &, 153 & 1,000 \\
\hline Sig. (1-tailed) & Posttest & $\cdot$ &, 233 \\
& Buku Ajar Bahasa Jawa &, 233 &. \\
\hline N & Posttest & 25 & 25 \\
& Buku Ajar Bahasa Jawa & 25 & 25 \\
\hline
\end{tabular}


Tabel di atas menggunakan hubungan antara buku ajar bahasa jawa piwulang 5 pengalamanku. Korelasi pearson digunakan untuk mengukur keeratan hubungan antara kedua variabel tersebut. besar korelasinya adalah 0,153 (korelasi positif).

\begin{tabular}{|l|r|r|r|r|}
\multicolumn{7}{c|}{ Model Summary } \\
\hline Model & R & R Square & $\begin{array}{l}\text { Adjusted } \\
\text { R Square }\end{array}$ & $\begin{array}{r}\text { Std. Error of } \\
\text { the Estimate }\end{array}$ \\
\hline 1 &, $153^{\mathrm{a}}$ &, 023 &,- 019 & 11,18034 \\
\hline
\end{tabular}

a. Predictors: (Constant), Buku Ajar Bahasa Jawa

$\mathrm{R}=0,153$ besarnya koofisien. Korelasi antara buku ajar bahasa jawa piwulang 5 pengalamanku dengan hasil belajar siswa posttest.

R Square sebesar 0,023 artinya 2,3\%. Hal ini menunjukkan bahwa perubahan hasil belajar siswa ditentukan oleh buku ajar bahasa jawa sebesar 2,3\% sedangkan 97,7\% peningkatan siswa ditentukan oleh variabel lain diluar variabel dalam penelitian ini. Sehingga dapat dibuat interpretasi bahwa buku ajar bahasa jawa piwulang 5 pengalamanku cukup berpengaruh terhadap hasil belajar siswa kelas I pelajaran bahasa jawa piwulang 5 pengalamanku di MI Nurur Rohmah Jasem Sidoarjo.

\section{PEMBAHASAN}

\section{Pengembangan Buku Ajar}

\section{a. Pengertian Buku Ajar}

Suatu komponen sistem pembelajaran yang menjadi peranan penting dalam mencapai Standar Kompetensi (SK) dan Kompetensi Dasar (KD) adalah Buku Ajar. Buku ajar adalah jenis buku yang digunakan sebagai ilmu pengetahuan dasar, dan digunakan sebagai sarana pembelajaran. ${ }^{15}$

Menurut suharjono, buku ajar merupakan buku yang digunakan sebagai media pembelajaran yang dilengkapi sarana-sarana pengajaran yang serasi dan mudah dipahami oleh para peserta didik dan mahasiswa sehingga dapat menunjang suatu program pembelajaran. ${ }^{16}$ Mintowati juga menjelaskan bahwa buku ajar merupakan salah satu media pembelajaran yang dapat menunjang keberhasilan proses belajar mengajar. Buku ajar adalah suatu kesatuan pembelajaran yang berisi informasi, pembahasan dan evaluasi

\footnotetext{
${ }^{15}$ Khaerudin Kurniawan, Handout Mata Kuliah Menulis Buku Ajar/Ilmiah (IN309), 2

${ }^{16}$ Digilib.unila.ac.id.pdf,9
} 
Dari pengertian diatas dapat disimpulkan bahwa buku ajar adalah buku yang digunakan sebagai penunjang keberhasilan peserta didik untuk memahami materi yang sedang diajarkan. Biasanya digunakan sebagai bekal pengetahuan dasar dan sebagai sarana pembelajaran baik di sekolah dasar dan perguruan tinggi. Dengan adanya buku ajar, kegiatan belajar mengajar di sekolah menjadi lebih efektif.

\section{b. Fungsi Buku Ajar}

Peranan dan manfaat buku ajar menurut Greene dan petty, diantaranya ${ }^{17}$ :

1) Sebagai sudut pandang yang modern mengenai bahan pengajaran yang disajikan.

2) Untuk menyajikan sumber pokok masalah yang bervariasi dan mudah dipahami sesuai dengan kebutuhan peseerta didik.

3) Untuk menyediakan sumber yang tersusun rapi dan sesuai dengan keterampilanketerampilan yang ekspresional.

4) Untuk memotivasi peserta didik dengan adanya penyajian metode dan sarana pembelajaran.

5) Sebagai penunjang latihan dan tugas-tugas pelajaran.

6) Untuk menyajikan bahan evaluasi yang serasi dan tepat guna.

\section{c. Prinsip-Prinsip Penulisan Buku Ajar}

Berdasarkan buku pedoman penulisan buku ajar oleh degeng dijelaskan prinsipprinsip penulisan buku ajar ${ }^{18}$, diantaranya:

1) Prinsip relevansi (keterkaitan).

2) Prinsip konsistensi.

3) Prinsip kecukupan.

4) Sistematika.

\section{d. Bahasa Jawa}

Bahasa merupakan sistem lambang bunyi yang dipergunakan untuk berkomunikasi, bekerjasama, dan mengidentifikasi diri oleh kelompok sosial. Dalam masyarakat indonesia, kata bahasa sering dipergunakan dalam berbagai konteks dan berbagai makna. ${ }^{19}$ Senada dengan abdul chaer dan Leoni agustina, bahwa bahasa adalah alat untuk berkomunikasi dan berinteraksi sosial yang paling baik di antara alat komunikasi lainnya. ${ }^{20}$

\footnotetext{
${ }^{17}$ Digilib.unila.ac.id.pdf, 11-12

${ }^{18}$ Ibid., 13

${ }^{19} \mathrm{Hp}$ Ahmad dan Abdullah Alek, Linguistik Umum (Jakarta, Penerbit Erlangga, 2012), 3

${ }^{20}$ Chaer Abdul dan Agustina Leonie, Sosiolinguistik Perkenalan Awal Edisi Revisi ( Jakarta, PT Rineka Cipta, 2004$), 47$
} 
Jadi, bahasa jawa merupakan alat komunikasi manusia yang digunakan untuk berinteraksi yang biasanya digunakan oleh penduduk bersuku bangsa jawa. Yang didalamnya mengandung kekhasan bahasa berupa ragam bahasa berupa ngoko dan krama dan menjadi salah satu karakteristik yang membedakan bahasa jawa dengan bahasa yang lainnya.

\section{Piwulang 5 pengalamanku}

Menurut kamus besar bahasa indonesia piwulang adalah pelajaran. ${ }^{21}$ Jadi, maksud $^{2}$ dari piwulang 5 adalah pelajaran 5. Pengalamanku adalah hasil persentuhan alam dengan panca indra manusia. Berasal dari kata peng-alam-an. Pengalaman memberikan suatu pengetahuan dari yang tidak tahu menjadi tahu. ${ }^{22}$ Dapat disimpulkan, bahwa piwulang 5 pengalamanku adalah pelajaran 5 yang didapatkan dari hasil persentuhan alam dengan manusia, dari yang tidak tahu menjadi tahu.

\section{a. Jenis-jenis Pengalaman}
1) Pengalaman menyenangkan
2) Pengalaman menyedihkan

\section{b. Manfaat pengalaman}

1) Mengajarkan arti hidup yang sebenarnya

2) Dapat mengambil hikmahnya

3) Kita dapat belajar menjadi lebih baik lagi

Secara harfiah, istilah karakter berasal dari bahasa inggris 'character' merupakansifat atau watak. Karakter merupakan pembeda antara budi pekerti seseorang dengan yang lainnya yaitu sifat kejiwaannya, tabiat, dan akhlak. Wyne dalam E.Mulyasa mengemukakan bahwa karakter berasal dari bahasa yunani yang berarti "to mark" (menandai) dan memfokuskan bagaimana menerapkan nilai-nilai kebaikan dalam tindakan nyata atau perilaku sehari-hari.

Hanya 2 karakter yang digunakan dan ditanamkan pada diri anak-anak dalam pengembangan buku ajar yaitu karakter religius dan karakter tanggung jawab. Dari kedua karakter tersebut dapat dijelaskan sebagai berikut:

1) Religius, yakni taat dan patuh terhadap ajaran agama yang di anut, seperti toleransi terhadap agama lain, serta rukun dan berdampingan. Indikator yang tercantum dalam karakter religius:

a. Karakter Religius

\footnotetext{
${ }^{21}$ Kamus Besar Bahasa Indonesia edisi 3. Hak cipta Pusat Bahasa (Pusba).

${ }^{22}$ Vardiansyah dan Dani, Filsafat Ilmu Komunikqasi: Suatu Pengantar (Jakarta: Indeks, 2008), 3
} 
1) Mengucap salam

2) Berdo'a sebelum dan sesudah belajar

3) Menggunakan bahasa yang santun

2) Tanggung jawab yakni perilaku yang mencerminkan kewajiban dalam melaksanakan tugas. Indikator yang tercantum dalam karakter tanggung jawab:

b. Karakter Tanggungjawab

1) Mengerjakan tugas yang diberikan guru tepat waktu

2) Menyerahkan tugas tepat waktu

\section{E. SIMPULAN}

1. Tingkat kelayakan dan efektifitas buku ajar bahasa jawa piwulang 5 pengalamanku ini dapat dikatakan layak, karena hal ini dapat di buktikan dengan adanya hasil uji coba produk. Untuk mengetahui kelayakan produk ini peneliti melakukan penilaian kepada para ahli.

2. Berikut ini yang diperoleh untuk menguji kelayakan buku ajar bahasa jawa piwulang 5 pengalamanku : Hasil validasi dari ahli desain sebesar 30\% yang artinya belum layak digunakan, ahli konten sebesar $60 \%$ yang artinya sudah layak digunakan, validasi ke-1 ahli bahasa sebesar $40 \%$ yang artinya belum layak digunakan, ke-2 50\% yang artinya belum layak digunakan, ke-3 100\% yang artinya sudah layak digunakan. Keefektifan buku ajar bahasa jawa piwulang 5 pengalamanku ini diperoleh dari hasil belajar siswa berdasarkan uji coba lapangan yang dianalisis dengan SPSS 15. Hasil analisis uji t terhadap nilai pretest menunjukkan nilai rata-rata 60,40 dan hasil posttest 86,80 . Oleh karena nilai $\mathrm{p}$-value statistik uji $\mathrm{t}$ adalah sebesar 0.00 yang berarti $(<0.05)$, maka dapat disimpulkan bahwa Ho ditolak dan Ha diterima. Hal tersebut berarti terdapat pengaruh yang signifikan dari diterapkannya buku ajar bahasa jawa piwulang 5 pengalamanku.

3. Faktor pendukung dan penghambat Penerapan Buku Ajar Piwulang 5 Pengalamanku Berbasis Karakter Islam Kelas 1 MI Nurur Rohmah Jasem Sidoarjo.

a. Faktor pendukung : lingkungan belajar, siswa, buku ajar piwulang 5 pengalamanku, dan pengajar dan peneliti.

b. Faktor penghambat : alokasi waktu, dan pengelolahan kelas. 


\section{DAFTAR PUSTAKA}

Abdul Chaer dan Agustina Leonie, Sosiolinguistik Perkenalan Awal Edisi Revisi Jakarta: PT Rineka cipta,2004.

Ahmad Hp dan Abdullah Alek,Linguistik Umum, Jakarta: Penerbit Erlangga, 2012.

Arikunto, Dasar-Dasar Evaluasi Pendidikan, Jakarta: Bumi Aksara, 2003.

A.S Ridwan dan Muhammad Kadri, Pendidikan Karakter: membangun karakter yang islami, Jakarta : Bumi Aksara,2016.

Azizah Nur,Pengembangan Buku Bacaan Cerita Rakyat Bahasa Jawa Berbasis Kontekstual di Kabupaten Brebes, Skripsi S-1, Fakultas Bahasa dan Seni UNNES, 2013.

Arsyad Azhar,Strategi dan Implementasi Pendidikan Karakter Bangsa di Perguruan Tinggi,makalah Disampaikan Atas Permintaan Kasubit Akademik, Direktorat Perguruan Tinggi Agama Islam, Kementrian Agama RI Jakarta, 2011.

Baharuddin, Pendidikan dan Psikologi Perkembangan, Yogyakarta: Ar-Ruzz Media,2009.

Budiarti Sri Agung,Pengembangan Komik Bilingual (Bahasa Indonesia - Bahsa Jawa) Sebagai media Pembelajaran Kimia Pada materi Pokok Asam Basa Kelas IX, Skripsi S1 Fakultas Sains dan Teknologi UIN Sunan Kali Jaga Yogyakarta,2013.

Departemen Agama, Kantor Wilayah Provinsi Jawa Timur, Standar Nasional Pendidikan UU PERMEN NO 22 TAHUN 2006 Tentang Standar Isi, Surabaya

Digilib.unila.ac.id.pdf

Idris Zahara, 1992. Pengantar Pendidikan 2, Padang : Angkasa Raya

Kamus Besar Bahasa Indonesia edisi 3. Hak cipta Pusat Bahasa (Pusba).

Kemendikbud, Panduan Teknis Penilaian Di Sekolah Dasar, Kurikulum 2013 Sekolah dasar

Kurniawan Khaerudin, Handout Mata Kuliah Menulis Buku Ajar/Ilmiah (IN309)

Majid Abdul dan Dian Andayani,Pendidikan Karakter Prepektif Islam, Bandung: Remaja Rosda Karya,2012.

Megawangi Ratna, Pendidikan Karakter Solusi Yang Tepat Untuk Membangun Bangsa, Jakarta: BP Migas Star Energy,2004.

Marzuki, Prinsip Dasar Pendidikan Karakter Prespektif Islam, 4 dalam (http://staff.uny.ac.id/sites/default/files/pengabdian/dr-marzuki-mag/dr-marzuki-magprinsip-dasar-pendidikan-karakter-perspektif-islam.pdf)

Mulyasa E, Manajemen Pendidikan Karakter, Jakarta: Bumi Aksara,2011., Pengembangan dan Implementasi Kurikulum 2013, Bandung: PT. Remaja Rosdakarya,2013. 
Muslich Masnur,Pendidikan Karakter Menjawab Tantangan Krisis Multidimensional, Jakarta: Bumi aksara,2011.

Nata Abuddin, Manajemen Pendidikan: Mengatasi Kelemahan Pendidikan Islam di Indonesia, Jakarta : Kencana,2008.

Ningrum Sulistya Wara, "Identifikasi Kebutuhan Pendidikan Karakter Di Sdn Inpres 1 Tondo Kecamatan Palu Timur,(https://id.scribd.com/doc/220864524/Jurnal-PendidikanKarakter-pdf)

Muhammad, M., \& Nurdyansyah, N. (2015). Pendekatan Pembelajaran Saintifik. Sidoarjo: Nizamia learning center.

Nurdyansyah, N., \& Andiek, W. (2015). Inovasi teknologi pembelajaran. Sidoarjo: Nizamia learning center.

Nurdyansyah, N., \& Fahyuni, E. F. (2016). Inovasi Model Pembelajaran Sesuai Kurikulum 2013. Sidoarjo: Nizamia learning center.

Nurdyansyah, N., Rais, P., \& Aini, Q. (2017). The Role of Education Technology in Mathematic of Third Grade Students in MI Ma'arif Pademonegoro Sukodono. Madrosatuna: Journal of Islamic Elementary School, 1(1), 37-46.

Nurdyansyah, N. (2016). Developing ICT-Based Learning Model to Improve Learning Outcomes IPA of SD Fish Market in Sidoarjo. Jurnal TEKPEN, 1(2).

Nurdyasnyah, N., \& Andiek, W. (2017). Manajemen Sekolah Berbasis ICT. Sidoarjo: Nizamia learning center.

Nurdyansyah, N. (2018). Model Pembelajaran Berbasis Masalah Pada Pelajaran IPA Materi Komponen Ekosistem. Universitas Muhammadiyah Sidoarjo.

Nurdyansyah, N. (2018). Peningkatan Moral Berbasis Islamic Math Character. Universitas Muhammadiyah Sidoarjo.

Nurdyansyah, N. (2018). Pengembangan Bahan Ajar Modul Ilmu Pengetahuan Alambagi Siswa Kelas Iv Sekolah Dasar. Universitas Muhammadiyah Sidoarjo.

Nurdyansyah, N., \& Fitriyani, T. (2018). Pengaruh Strategi Pembelajaran Aktif Terhadap Hasil Belajar Pada Madrasah Ibtidaiyah. Universitas Muhammadiyah Sidoarjo.

Nurdyansyah, N. (2017). Sumber Daya dalam Teknologi Pendidikan. Universitas Muhammadiyah Sidoarjo.

Nurdyansyah, N. (2015). Model Social Reconstruction Sebagai Pendidikan Anti-Korupsi Pada Pelajaran Tematik di Madrasah Ibtida'iyah Muhammadiyah 1 Pare. Halaqa, 14(1).

Rohmat Mulyana, Mengartikulasikan Pendidikan Nilai, Bandung: Alfabeta,2004. 
Rubrik Penilaian Kurikulum 2013, Buku Guru Pendidikan Agama Islam dan Budi Pekerti, Jakarta: Kementerian Pendidikan dan Kebudayaan,2014.

Rusyanti Hetty , pengertian bahan ajar menurut ahli, (http://www.kajianteori.com/2014/02/ pengertian bahan ajar menurut ahli.html).

Sani Ridwan Abdullah dan Muhammad Kadri,Pendidikan Karakter: Mengembangkan Karakter Anak Yang Islami, Jakarta: Bumi Aksara,2016.

Setiowati Amrih, Pengembangan Buku Berbahasa Jawa Bergambar sebagai Penunjang Pembelajaran Bahasa Jawa Sekolah Dasar, Skripsi S-1, Fakultas Bahasa dan Seni UNNES,2013.

Sutarjo Adisusilo,Pembelajaran Nilai - Karakter (Kontsruktivisme dan VCT Sebagai Inovasi Pendekatan Pembelajaran Afiktif),Jakarta: PT. RajaGrafindo Persada, 2013.

Suyadi,Strategi Pembelajaran Pendidikan Karakter, Bandung: PT Remaja Rosdakarya,2015.

Sugiyono, Metode Penelitian Kuantitatif, Kualitatif, dan R\&D, Bandung: Alfabeta,2014.

Taufiq Ahmad dan Muhammad Rohmadi,Pendidikan Agama Islam, Surakarta: Yuma Pustaka,2012.

Undang-undang Republik Indonesia NO. 20 Th. 2003 tentang sisdiknas, bab 1 pasal 1 ayat 1 (http://sindikker.dikti.go.id/dok.UU/UU20-2003-Sisdiknas.pdf)

Ulwan Nasih A,Tarbiyatul Awlaad Fi Al-Islaam, Cet.XXI, Jilid I, Jeddah: Daarussalaam, 1992.

Vardiansyah dan Dani,Filsafat Ilmu Komunikqasi: Suatu Pengantar, Jakarta: Indeks,2008.

Walter Dick and Lou Carey, The Systematic Design of Instruction, New York: Harper CollinsPublishers, 2001.

Https://id.wikipedia.org/wiki/bahasa_jawa

http://eprints.uny.ac.id/9378/3/BAB\%202\%20-\%2007601241082.pdf 